Далиборка Вукасовић

Основна и средња школа „Петро Кузмјак“

Руски Крстур

vukasovicdaliborka@gmail.com

https://doi.org/10.18485/rit.2021.19.35.4
УДК: $121(37+38)^{“ "}-02 /-00 “$

$171(37+38)^{\prime \prime}-02 /-00$ “"

Оригинални научни рад

Датум пријема: 11.12.2020.

\title{
„СТИД И ПОНОС КАО ОДНОС ЧОВЕКА ПРЕМА САМОМ СЕБИ' У ХЕЛЕНИСТИЧКОЈ ФИЛОЗОФИЈИ
}

\section{Резиме}

У свом йоиману самоїа себе човек јестие йраїалаи који сйознаје gа је биће оgноса иррема самом себи и иррема gруіима. Рефлексија о йосйојану gруїих и gруїої јестие референитни оквир у којем се сажима мишљење о ономе шйа човек јесте и какав јестие. Љуяи ӣостиају љуgи међу љуgима, човеку gа би био човек йойребан му

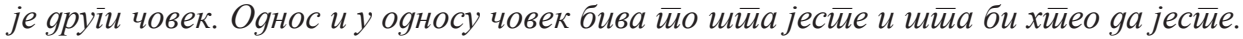
Наиме, кроз динамику оgноса човек се ойкрива себи и яруіима са врлином и маном, наїраяом и казном, йобедом и іуббииком са којим су скойчани стиия и йонос. У сиииgу човек заклања лице оg gруіих у йоносу їа ойкрива. Сйарање о себи „ерітеleia hеаитои" јестие начело сйознаје које се иройеже кроз целу хеленисиичку филозо-

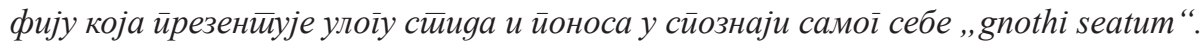

Кључне речи: оgнос, стиарање о себи, хеленистичка филозофија, стиия, йонос, gap, epimelia heautou, gnothi seatum.

Херменеутика човека као субјекта спознаје открива се у истини која јесте не само епистемолошка категорија већ и онтолошка. Човек сазнаје, познаје призму свог битисања кроз динамику супротности, променљивости, коначности где интенција спознаје себе уједно јесте покушај преображења себе. Човек као створено биће јесте биће које је даровано даровима мишљења, говора, стида, правде, ватре. Дарови се откривају као дистинкција између човека и света али и као спознаја о бићу који дар поседује. Аспект поимања човека као бића које је даровано даровима, између осталог да буде човек јесте да је недостатно биће. Недостатност је иманентна човеку као пролазном, коначном бићу који јесте део вечно постојећег поретка оличеном у свету који затиче и оставља.

Динстикција јесте оквир рефлексије где се зачиње свест о недостатности спрам односа човека као микрокосмоса „малог света“" и макрокосмоса „великог света“. Разлика јесте у односу разумевања себе и света, од- 
46 Далиборка Вуксановић: „Сйиg и йонос као оунос човека ирема самом себи “...

нос се зачиње у начелу „gnothi seatum - спознај самог себе“ којем претходи „,epimelia heautou - старање о самом себи“. Императив „старање о себи“ јесте однос према себи, другима, свету примарно укључује одређен начин бдења над оним о чему човек размишља и над оним што се збива у мишљењу (Фуко, 2001: 23) Бдење над самим собом јесте почетак рефлексије између субјекта и истине чији је епилог спознаја себе сама. Важност спознаје очитује се у односу где стид као дар богова човеку као недостатном бићу доноси спознају о прекорачењу задате мере, границе у односу на друге, другог. У миту о Протагори стид је поред правде највећи дар дат човеку јер представља могућност за уређени социјални живот заједнице, полиса.

„Зевс се, дакле, уплаши за наш род да цео не пропадне, те пошаље људима Хермију са стидом и правдом да то буде украс градова и присна веза пријатељства. Тада Хермија упита Зевса, на који би начин дао правду и стид људима. „Да ли да онако како су вештине расподељене поделим и ово? А оне су овако подељене један има лекарску вештину, и он је довољан за многе нестручњаке, а овако ствар стоји и с другим занатлијама. Да ли да овако и правду и стид да поставим међу људе или да их свима поделим?“

„Свима“, рече Зевс, нека сви имају! (Платон, 1968 : 20)

Стид је дар са којим се рађа „нови човек заједнице“ који и своју потврду људскости остварује у заједници са другима и кроз друге. Стид је нужност битисања који конституише обичајну, моралну вертикалу која чини дату заједницу постојећом. Сви људи су позвани да имају стид, Платон у поменутом миту каже: „Јер градови не би могли постати када би их само мало њих имало, као што ствар стоји с другим вештинама. И закон постави од мене: ко не може да има стида и правде, нека га убију као несрећу града““ (Платон, 1986: 20). Стид даје дигнитет човеку који је у облигацији да га има, чува јер стид је мера у односу на себе и друге. Мера јесте парадигма хеленске цивилизације поимања човека и његовог света . „Megen agan - ничег превише“ јесте начело спрам којег човек јесте човек у односу на себе и свет. Megen agan ce интернализује у „sophrosyné - софросине“ која представља унутрашњи хабитус човековог карактера у настојању воље ка умерености, трезвености, разборитости.

Софросине своју персонификацију проналази у митологији у лику богиње Нимесис коју прати стид (Aidos) а која опомиње људе на умереност. Мера као однос у хеленској филозофији није само део праксиса човековог деловања, устројства његове бити већ је и део односа ка божанским. „Рan metron ariston - све са мером“, јесте нужност односа људи и богова који се 
руше оног тренутка када човеком овлада „хибрис“. Прекомерност, охолост, обест, понос јесу перогативи хибриса. Понос јесте гранични појам спознаје човека као бића који у Ничеовом смислу „преврендује“ сам себе. Хибрис је метафора за прекорачење „megen agan“, мера је нужност људског и божанског поретка. Понос као осећање вредновања самог себе, својих поступака у односу на друге у самом човеку рађа осећање задовољства а не ретко и охолости. Понос је „уздизање самог себе у односу на друге“ чиме се губи мера. У хеленској представи понос је поиман као осећање које овладава самим човеком што имплицира губљењем сопства јер све оно што је узвишено и високо руши, кажњава богиња Немесис.

Понос и стид јесу однос мере које човек сам ствара у односу на себе и друге. Од зависности какав је човек таква ће бити и мера односа поноса и стида. Принцип мере проналази пут до човековог бића преко „еpimeleia heautou“ или старања о самом себи. Човек да би имао меру свог бића у односу спрам себе и других неопходна је спознаја која води ка мери. Мера је модус постојања јер ван ње постојање није ни могуће, човек губи сам себе. Epimeleia heautou jе став према себи, другима, свету облик пажње окренуте ка себи. Epimeleia увек значи и извесни број радњи, дела која се обављају од себе на себи, радњи кроз које човек преузима бригу о себи, кроз које се мења, којима се чисти и којима се преобликује и преображава. Одатле читав низ пракси које ће у историји западне културе, филозофије, морала, духовности дуго живети нпр. медитација, технике памћења прошлости, технике испита савести (Фуко, 2001: 24). Стид и понос у извесној мери јесу продукт пажње усмерене над самим собом.

Стид и понос јесу унутрашња мерила понашања, деловања у којима се човек као морално биће потврђује као добро или лоше у зависности од постављених моралних параметара заједнице којој припада. Човек као делатно биће подложно је оцени и самооцени свог деловања, поступања. С обзиром на структуру учињеног дела јављају се морални осећаји стида, поноса са којим су повезани осећање кривице, кајања.

Стид и понос јесу морални осећаји који имплицирају вредносну процену поступања у односу на себе и друге као добро или лоше. Као морални осећаји који су условљени односом, поступком, проценом стид као и понос у суштини представљају одређени „хабитус“ (држање тела).

Хабитус је „држање“ самог себе у односу на поступање, деловање у склопу повољних и неповољних околности у којем се деловање одвија. Хабитус „држање тела“ је израз слободне воље самог човека да бира, одлучу- 
48 Далиборка Вуксановић: „Сйиg и йонос као оунос човека ирема самом себи “...

је о свом држању, да ли ће остати у мери свог бића или ће је прекорачити. Добро је у мери „megan again - ничег исувише“ добро поступање, деловање изречено у духу хеленизма јесте начело „златне средине“. Општи карактер средине јесте људска врлина која изражава вредност мере која се протеже и на космичку раван. „људска врлина се тиме утемељује као слика космичке мере, те омогућује у полису власт бољих над лошијима, а у души власт ума над пожудама, која човека чини 'властитим господарем', јер је нашао праву меру односа према боговима и људима, те тиме постао честит у свим елементима. Губитак праве мере у души прети јој пропашћу, као што и губитак мере у полису води његовом распадању“ (Перовић, 2001: 368).

Стид и понос као морални осећаји који се рефлектују кроз држање тела иманентни су човеку и као такви присутни су у свим културама, духовним и филозофским праксама кроз историју људског рода. Стид и понос су Ничеовим језиком речено оно „људско исувише људско“ где је не тако ретко тешко пронађи „праву меру“ у односу на себе и друге. Стид и понос као однос могу успоставити корелације на предмете, субјекте поштовања којим припадају...

Као морална осећања стид и понос јесу референтни оквири разумевања, вредновања, усмеравања сопства ка себи и другима. Такође, омеђују границе дозвољеног и не дозвољеног у етосу којем припадају. Мит о Нарцису сведочи о поносу, о загледаности човека у самога себе, у одраз свога бића као јединој супериорној реалности која надвладава на крају и њега самога где он по закону „,megan again“ губи самог себе. Прича о Нарцису јесте прича о егоцентризму који своје исходиште има у поносу као носиоцу ега који искључује, затвара човека у самог себе спрам света, других.

У субјективном односу стид и понос као морална осећања јесу индикатори човека као бића слободе да изражава своје сопство на себи својствен начин у датим приликама. Стид и понос јесу спознаје мере слободе и одлуке о ономе како човек себе презентује поступком себи и другима. У стиду и поносу се крије и жеља самога човека и његове презентности како жели да га други виде, открију, разумеју. Као недостатно, коначно биће стид и оно од чега се стиди као и понос и оно на шта је поносан откривају пут разумевања, схватања човека као несавршеног бића. 


\section{Закључак}

Стид и понос јесу иманентни човеку у митском и хеленистичком мишљењу појмљени као дарови који имају задатак да откривају саму нутрину човековог бића, људскост онога што као људи јесмо у односу према себи и другима. Такође, подсећају на људски заборав у односу на нас саме када прекорачимо „megan again“ јер мера је форма која обликује људе, догаћаје. Заборав да мера јесте у свему и да се мера мора имати спрам себе и других јесте усуд техничко-технолошке цивилизације којој припадамо.

\section{Литература}

Фуко, М. (2001). Херменеутика субјекта. Нови Сад : Светови

Платон. (1968). Протагора. Београд : Култура

Георг, Х. (1962). Историја филозофије. Београд : Култура

Кубурић, 3. и сарадници (2001). Филозофија - проблемски приступ. Нови Сад : Филозофски факултет

Драгана, Д. (1995). Увод у филозофију. Београд : Завод за уџбенике и наставна средства

Перовић, М. (2001). Етика. Нови Сад : Графомедиа 
50 Далиборка Вуксановић: „Се̄ия и йонос као оgнос човека иррема самом себи “...

\author{
Daliborka Vukasovic \\ Primary and Secondary School "Petro Kuzmjak" \\ Ruski Krstur \\ vukasovicdaliborka@gmail.com
}

\title{
"SHAME AND PRIDE AS A HUMAN \\ RELATIONSHIP TOWARDS HIMSELF" \\ IN HELLENISTIC PHILOSOPHY
}

\begin{abstract}
Summary
In his understanding of himself, the man is a seeker who realizes that he is a being of relationship to himself and to others. Reflection on the existence of others is another frame of reference in which the opinion on what a person is and what he is summarized. People become people among people; a man needs another man to be a man. In a relationship a person becomes what he is and what he would like to be. Namely, through the dynamics of the relationship, a person reveals himself and others with virtue and flaw, reward and punishment, victory and loss with which shame and pride are associated.

In shame, a man hides his face from others and when proud reveals it. Self-care "epimeleia heautou" is a principle of cognition that extends throughout Hellenistic philosophy which presents the role of shame and pride in self-knowledge "gnothi seatum".
\end{abstract}

Key words: relationship, self-care, Hellenistic philosophy, shame, pride, gift, "epimelia heautou”, "gnothi seatum”. 